\title{
LITHOSTRATIGRAPHY AND GEOCHEMICAL CHARACTERIZATION OF LIMESTONE DEPOSITS AROUND KUSHIMAGA AREA IN YOBE OF NORTH-EASTERN NIGERIA
}

\author{
U. A. Usman ${ }^{1,}{ }^{*}$, A. B. Abdulkadir ${ }^{2}$, J. M. El-Nafaty ${ }^{3}$, M. Bukar ${ }^{4}$ and S. Baba ${ }^{5}$

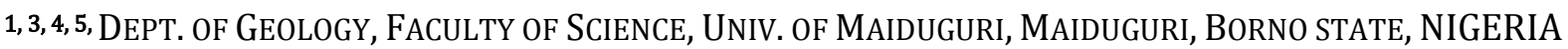 \\ 2, QuARry SECTION, ASHAKa ASHAKaCEM PlC. (A Subsidiary of LAFARGE AFriCA PlC), Gombe STATE, NIGERIA \\ E-mail addresses: ${ }^{1}$ attaayya@gmail.com, ${ }^{2}$ abatcha.babagana@lafargeholcim.com, \\ 3jaloel1960@yahoo.com, ${ }^{4}$ bukarmohammed2@yahoo.com, ${ }^{5}$ saidubaba@rocketmail.com
}

\begin{abstract}
This study presents detailed petrographic and chemical compositional characteristic of limestone deposits for possible industrial uses and specifications. The study area falls within the Gongola basin, North-eastern Nigeria. Core limestone samples were collected from four boreholes at the depth of approximately 25 metres each in Kushimaga area around Gulani in Yobe state; north-eastern Nigeria. Lithological units were observed in the following sequence; topsoil and clay with an average thickness of $1.513 \mathrm{~m}$, limestone $5.553 \mathrm{~m}$, shale $7.853 \mathrm{~m}$ respectively. Eleven limestone samples were selected from the boreholes for petrography and chemical analysis (Fluorescence Spectroscopy analysis). From the petrograhic studies the limestone samples are composed (visual estimate) of over 95\% calcite, trace amounts of colourless already recrystallized fossil of planktonic forams and mollusc, weakly deformed greenish grains of glauconite about 0.2 to $0.3 \mathrm{~mm}$ in grain size, traces of opaque, isotropic, high relief iron oxide minerals with 0.03 to $0.5 \mathrm{~mm}$ grains sizes are present disseminated in the form of limonite. Traces of quartz and feldspar grains of silt size class were also noted in thin sections. With less than $10 \%$ grains the samples are classified as mudstone. The results of chemical analyses of limestone shows a range values of $\mathrm{SiO}_{2}, 10.05 \mathrm{wt} \%$ to $32.00 \mathrm{wt} \%, \mathrm{CaO}, 21.00 \mathrm{wt} \%$ to $53.99 \mathrm{wt} \%, \mathrm{MgO}, 0.35 \mathrm{wt} \%$ to $1.00 \mathrm{wt} \%, \mathrm{Al}_{2} \mathrm{O}_{3}, 2.15 \mathrm{wt} \%$ to $12.69 \mathrm{wt} \%, \mathrm{Fe}_{2} \mathrm{O}_{3}, 1.28 \mathrm{wt} \%$ to $4.90 \mathrm{wt} \%, \mathrm{Na}_{2} \mathrm{O}, 0.002 \mathrm{wt} \%$ to $0.18 w t \%, \mathrm{~K}_{2} \mathrm{O}, 0.9 \mathrm{wt} \%$ to $1.96 \mathrm{wt} \%, \mathrm{TiO}_{2}, 0.21 \mathrm{wt} \%$ to $1.00 \mathrm{wt} \%, \mathrm{P}_{2} \mathrm{O}_{5}, 0.17 \mathrm{wt} \%$ to $0.69 \mathrm{wt} \%, \mathrm{MnO}, 0.21 \mathrm{wt} \%$ to $0.55 \mathrm{wt} \%$, loss on ignition, $21.98 \%$ to $36.87 \%$, while the result of chemical classification of the limestone show a range of $\mathrm{Ca} / \mathrm{Mg}, 23.33 \%$ to $125.68 \%$ and $\mathrm{Mg} / \mathrm{Ca}, 0.00 \%$ to $0.04 \%$ of the Kushimaga limestone. However, the limestone beds of the research area were compared with other standard chemical industrial specifications. The study revealed that the limestone around Kushimaga area satisfies the chemical factors for Portland cement production but falls below the standard chemical specifications for other industrial uses; glass, sugar and Paint pigments and filler productions.
\end{abstract}

Keywords: Argillaceous, bivariant, core, lithology, petrography and stratigraphy.

\section{INTRODUCTION}

The regional geology of the study area comprises of the basement rocks and the Cretaceous to Recent sediments as shown in Fig. 1 [1; 30; 34]. The Basement complex rocks occupy an area of about $600 \mathrm{~km}^{2}$ restricted to the south-western part of the Yobe state, [5]. The major rock types of the basement are the granites belonging to the Older granite suite although a few outcrops of gneisses and migmatites have also been mapped $[5 ; 16 ; 19]$. The Cretaceous and Tertiary sediments are predominantly restricted to the southern part of the Yobe state. These sediments include the Bima sandstone, Yolde Formation, Pindiga Formation comprising Kanawa member and Fika member and the Kerri-Kerri Formation. According to [5] several tiny Tertiary volcanic plugs, believed to be the northern extension of the Biu-Plateau are mapped as scattered outcrops in the southeast of the state.

The rocks of the study area is Kanawa Member of the Pindiga Formation which outcrops over a large part of the area mainly forming flat featureless topography. The Unit is made up of grey shale interbedded with thin often fossiliferous limestones. The Kanawa Member gives rise to black to dark grey clay soils often with limestone regolith $[4 ; 13 ; 31 ; 33]$. Limestone rocks are among the most essential of all the sedentary rocks. The carbonate rocks especially limestones are mineralogically composed mostly of minerals calcite. 


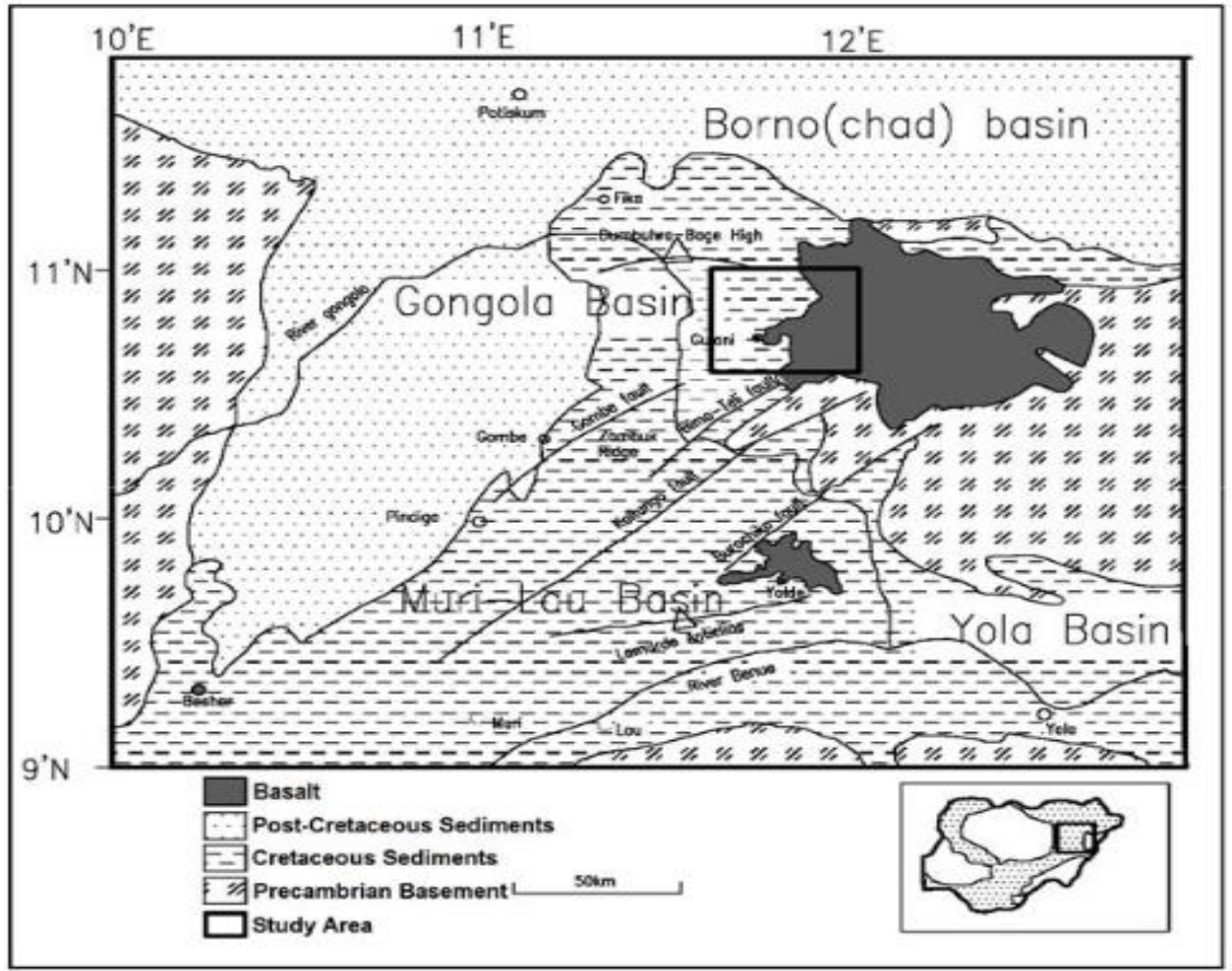

Figure 1: Geological map of the Upper Benue Trough showing the study area within the Gongola Basin [13].

They can also contain another carbonate mineral and many non-carbonates as impurities [8; 14; 22; 25; 29]. Previous research work was reported that some previous works in the region indicates, the $\mathrm{CaO}$ content which ranges from $43.04 \%$ to $53.04 \%$ shows that the limestone is of moderate quality [5]. The purest limestone documented in Nigeria is that of Mfamosing with a $\mathrm{CaO}$ content of 52 to $56 \%$ and a carbonate content $99 \%[2-3 ; 6 ; 12 ; 15]$.

This research work primarily focused on the quality assessment of the limestone deposits for the cement production and other building and construction purpose. The aim of the research was achieved through petrographic and geochemical studies.

\section{GEOLOGY}

The general geology of area consists of diorites, granites, sedimentary rocks of Bima sandstones, Yolde and Pindiga Formations and basalts (Figure 2).

The Precambrian Basement complex rocks of the area represented by diorite and granite inliers within Cretaceous sediments and Tertiary/Quaternary basalts. The study area is the Cretaceous formations comprising of Bima sandstone, Yolde Formation and two members of the Pindiga Formation [26; 28; 31; 37]. The area mainly found on outcrops of Limestone of Kanawa Member and Gulani Member (Figure 3), while the soft clayey soils formed on the "Kanawa Member" are generally devoid of settlements. Some bed exposed in the area comprise granulestone and very coarse to coarse-grained sandstones showing trough crossbedding. Poorly exposed intercalated pebbly sandstone was also recorded.

The Pidiga Formation is represented by Kanawa and Gulani members. The Kanawa member comprises of shales which in places are interbedded with limestone. The limestone in the area occurs as both crystalline and fossiliferous. The crystalline limestone is composed of calcite, quartz, dolomite and subordinate plagioclase and micro-cline while the fossiliferous type consists of calcite and dolomite [13].

\section{METHODOLOGY}

Field work was carried out in the study area. Eleven core limestone samples were collected from Ashaka Cement Plc. The rotary drilling method was used in collecting the core samples to reveal the underlying lithology, after pitting processes have demarcated the area of concentration of Limestone and shale.

Detailed lithologic description of the core samples was carried out with column for; depth, rock types and colour. Samples were then collected into well labelled sample bags for storage and laboratory analysis. 


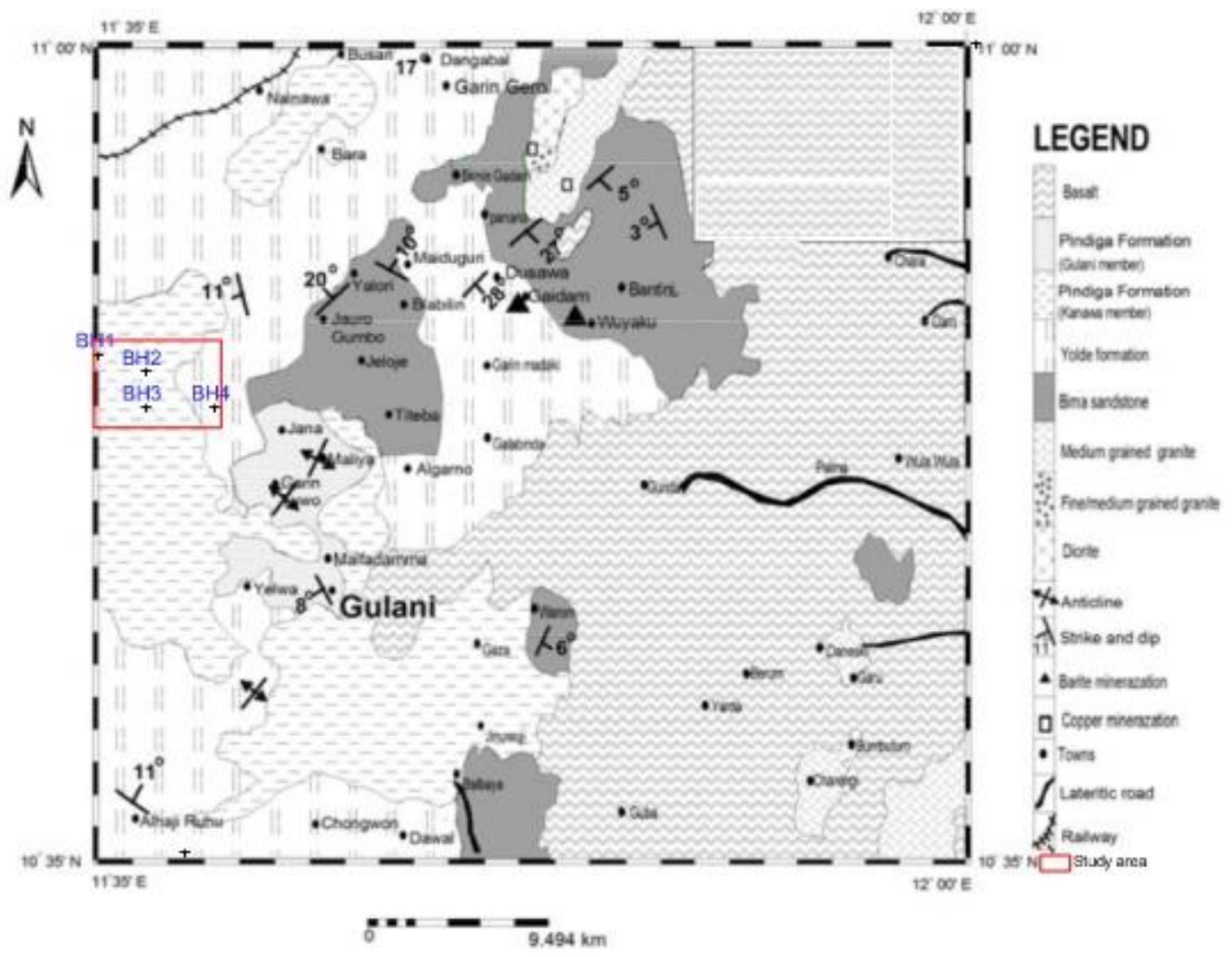

Figure 2: Geological Map of Gulani area showing the locations of Boreholes at Kushimaga [13].
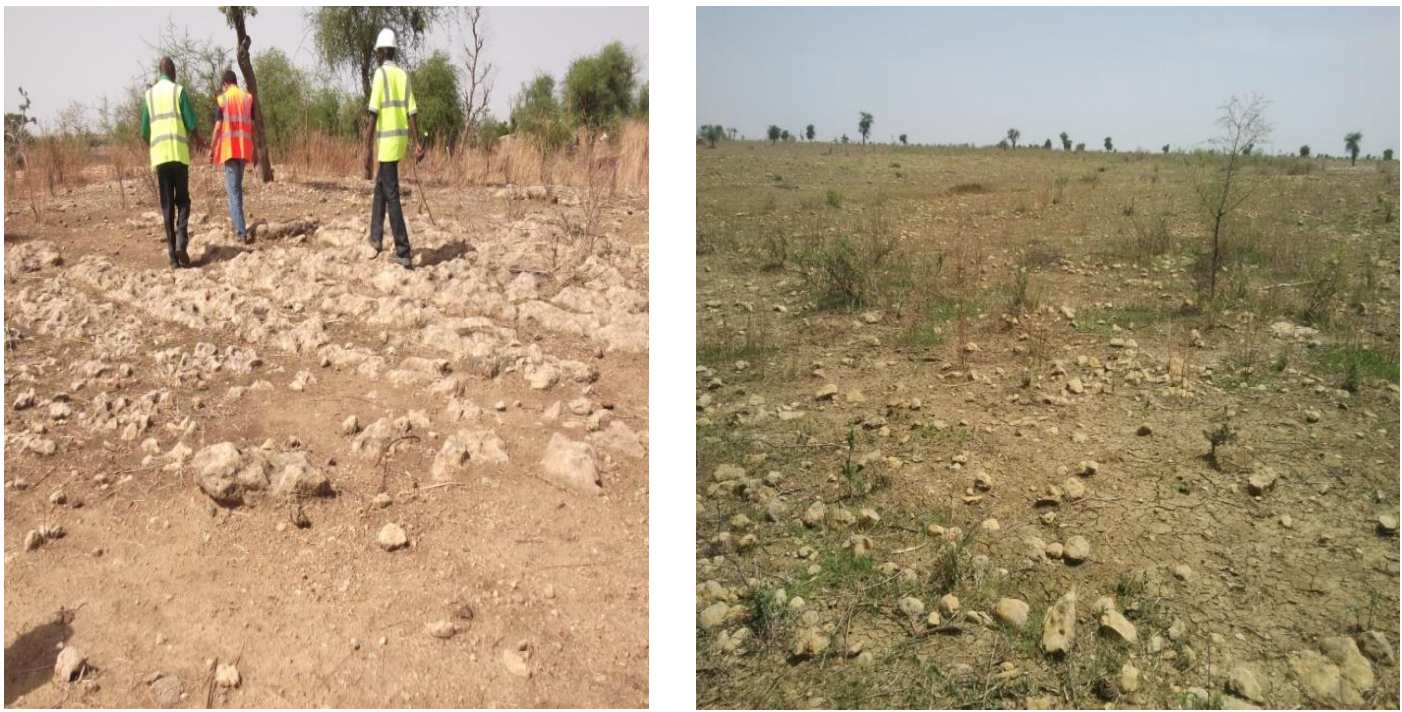

Figure 3: Exposure of Limestone on the earth surface at the study area.

The core samples were chipped to small pieces with geological hammer. The surface of the chipped sample was polished on the glass lap with the help of abrasive powder and water starting with coarse grade (90 grades), followed by 120 grades after a uniform surface of the samples, polishing was continuing with the various grades of the abrasive powders then finally the 800 grades was used. The abrasive powders were finally used in polishing the sample for the slide. Both polished sample and glass slide were placed on the hot plate; at $80^{\circ}-90^{\circ}$. The mixed araldite (epoxy or thermoplastic) with the wooden stirrer were smeared on the polish surface of the sample and mounted on the polished surface of the glass slide while still on the hot plate, for 5 - 19 minutes, and then were removed from the hot plate to a cold plate to cool down to room temperature.

The cutting or polishing machine was used to reduce the bulk of the sample, leaving about $0.66 \mathrm{~mm}$ or 60 microns thick of the sample, on the glass slide. 
Polishing with abrasive powder on the glass lap was repeated, until a thickness of $0.03 \mathrm{~mm}$ or 30 microns was reached. One will know that the 30 microns is reached, when quartz, feldspar or generally silica material get grey to white interference color. Blade was used to remove the over flow of the epoxy around the thin slice. The prepared slide was placed on the hot plate at the same temperature as stated above, and a drop of Canada balsam was added, then cover slip was placed over it, and gently pressed to remove the excess Balsam and air bubble. The slide could stay for $5-10$ minutes on the hot plate to solidify and removed to cool down to room temperature. The over flow of the Balsam was cleared by the side of the cover slip with the help of the organic solvent.

The slides were airdried and labeled and were now ready for use. Finally, the slides were used for the microscopic observation for mineral composition.

The Geochemical (PanAlytical AXIOS XRF) analysis was carried out at the Ashaka cement laboratory, (A Subsidiary of Lafarge Africa Plc), Gombe state, Northeastern Nigeria, with the aid of X-ray Fluorescence Spectroscopy method (PanAlytical AXIOS XRF). The fused beads were carried out through regrinding the core samples to $<60 \mu \mathrm{m}$, Drying raw with more than $0.5 \%$ moisture for 1 hour at $110^{\circ} \mathrm{C}$, weighing $2 \mathrm{~g}$ of sample into crucible and igniting in the furnace at $950^{\circ} \mathrm{C}$ was carried out, Reweighing the ignited samples and calculated the loss on ignition (LOI), Carefully breaking up/crushing the ignited samples using a spatula inside the crucible were prepared, from the ignited samples carefully weighing $1.0000 \mathrm{~g}$ into a clean dry fusion crucible was carried out, 8.0g added of flux and thoroughly mixed them together, $1.0 \mathrm{ml}$ of $25 \%$ $\mathrm{LiBr}$ solution using $1 \mathrm{ml}$ pipette was added but the samples were not mix after adding $\mathrm{LiBr}$, the crucibles were placed on the fusion machine holder, recipe (Recipe F) was selected, Pressing and holding start button for 10 seconds and releasing it was done, the machine automatically ignited and the fusion process is carried out by the Machine, At the end of the process, the machine indicated FUSION COMPLETE, labelling the bead while still in the mould on the outer surface were carried out and Glass Disk was used in removing and transferring the bead into the pellet cup but the surface was not in contact with the mould, there was no formation of crescent shape on the bead and we run the bead on XRF program "REFERENCE CURVE" for all samples made by this method.

SRM STD was used for the calibration. For the LOI Test, the furnace was set at $970^{\circ} \mathrm{C}$, followed by placing an empty crucible on the weighing balance and the reading was reset to zero, $1 \mathrm{~g}$ of the samples were weighed directly into the crucible, the crucible with the sample was taken out and balance machine was put to zero, followed by re-weighing the crucible with sample, followed by placing the crucible and sample in the middle part of the furnace using the crucible tong with carefulness, the furnace was closed and we allowed samples to remain in the furnace for 30 minutes, the samples were removed and placed into the desiccators and immediately covered and waited for the samples to cool, the crucible plus ignited samples were reweighed as M2 and LOI (Loss on Ignition) was calculated as:

$$
L O I=\left(M_{1}-M_{2}\right) \times 100 .
$$

The core samples were grounded by means of pulverizes agate mortar to less than 200 mesh size. Boric acid and dilatants are mixing to get a homogenous mixture and pellets were made. These were inserted into spectrometer for analyses. The elements determined include $\mathrm{Si}, \mathrm{Al}, \mathrm{Fe}, \mathrm{Ca}, \mathrm{Mg}, \mathrm{S}, \mathrm{Na}, \mathrm{K}$, Ti, P, Mn and LOI.

\section{RESULTS AND DISCUSSIONS}

\subsection{Lithological Description of Core Samples}

After studying at the lithological description of the boreholes, the limestone beds were found to be thick. The thickness of which vary from $0.70 \mathrm{~m}-9.95 \mathrm{~m}$. Shale interlayers are present in two of the five beds that is the one with thickness of $0.70 \mathrm{~m}$ and that of $9.95 \mathrm{~m}$ thickness. Those whose thickness is $3.57 \mathrm{~m}, 5.19 \mathrm{~m}$ and $7.99 \mathrm{~m}$ are free of shale interlayers. The limestones are massive, surface outcrops are dry. This study didn't determine the water table and the reserve estimation of the limestone area.

Four boreholes were drilled at suitable sites for limestone in the study area. The exercise revealed the presence of limestone bodies whose core samples are shown in Figure 4.

Lithological section of the boreholes is also presented in Figures 5 - 8 while the descriptions are given below. All the boreholes intercepted the Kanawa member only.

\subsubsection{Borehole No - 1 (Figure 5)}

The borehole is located at latitude $10^{\circ} 50^{\prime} 22.65^{\prime \prime} \mathrm{N}$ and longitude 11032'17.97" E. From the bottom of the borehole, shale was identified with dark brown colour, compacted on top of the layer while soft at the base. The shale bed overlaid by limestone which is yellowish grey in colour due. It is fragmented and intercalated with shale. On the top of limestone bed is the sandy clay with dark brown colour and slightly weathered. 

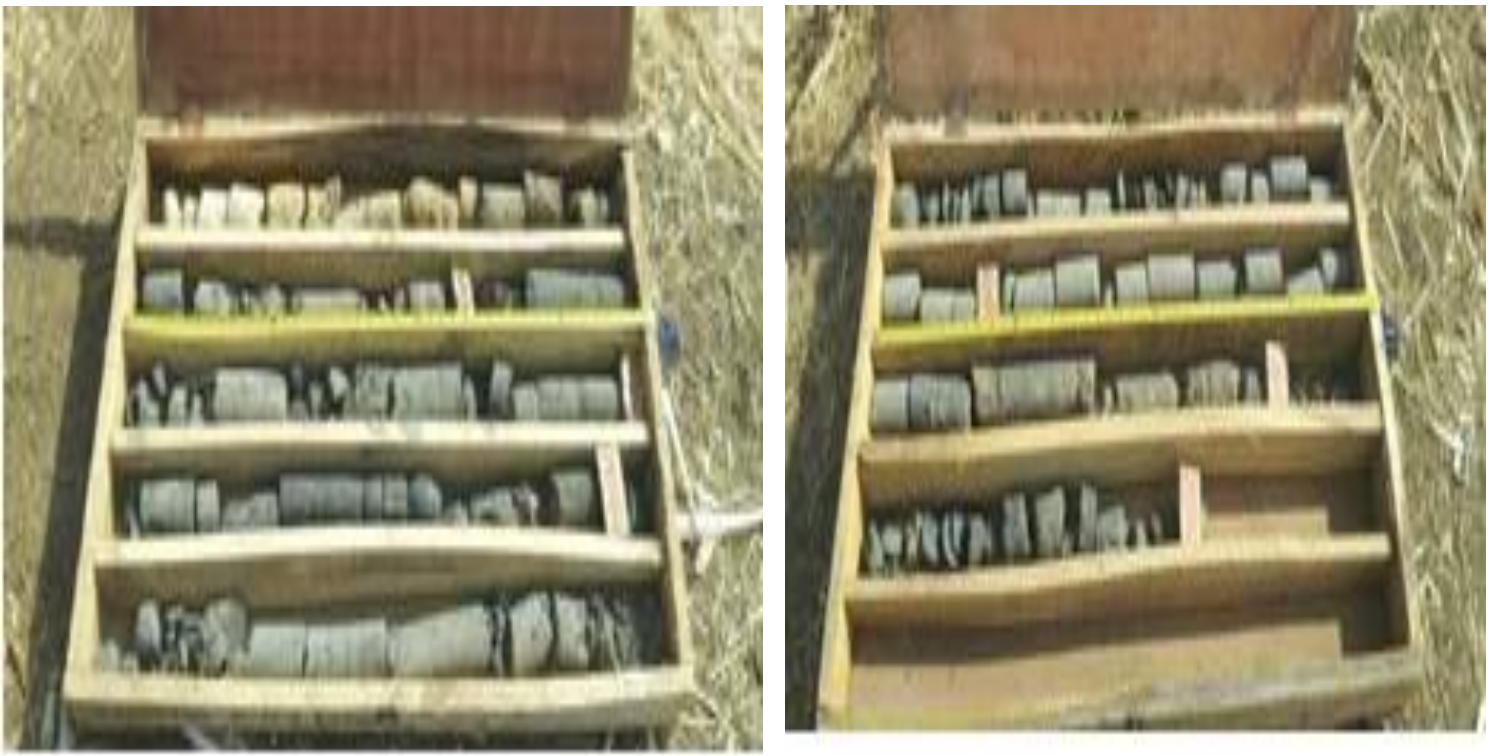

Figure 4: Borehole core samples of Kushimaga limestone deposit.

BH-1: Latitude: $10^{\circ} 50^{\prime} 22.65^{\prime \prime} \mathrm{N}$

Longitude: $11^{\circ} 32^{\prime} 17.97^{\prime \prime} \mathrm{E}$

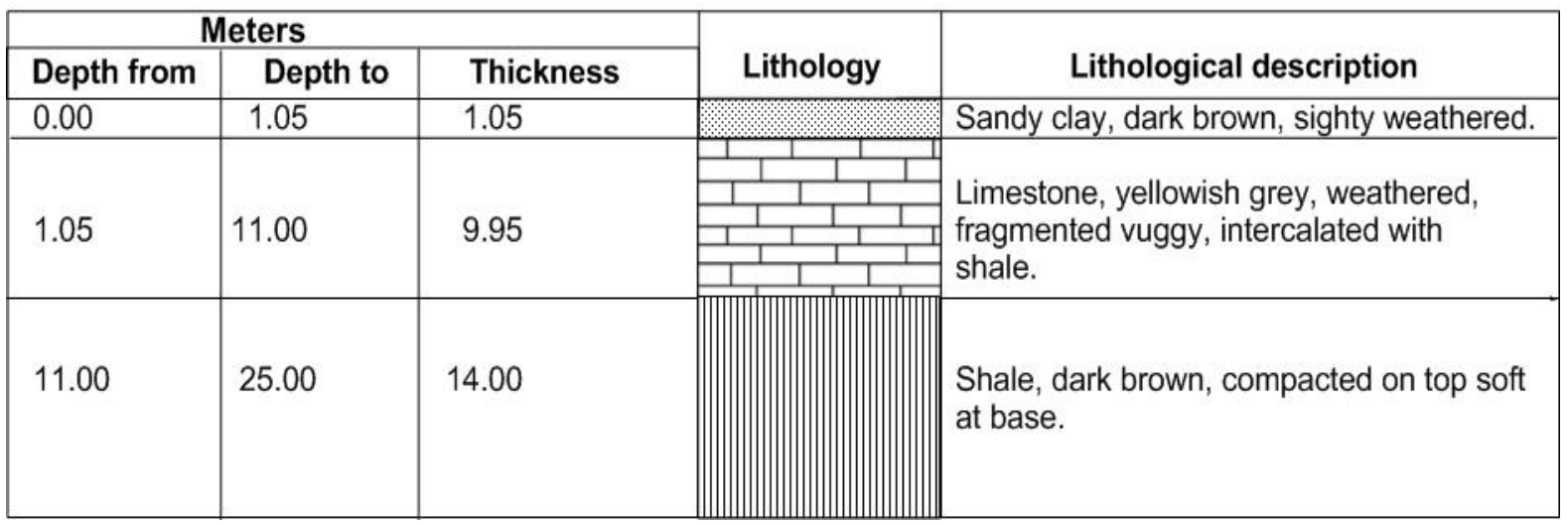

Figure 5: Lithological description of Borehole 1 at Kushimaga area, North-eastern Nigeria.

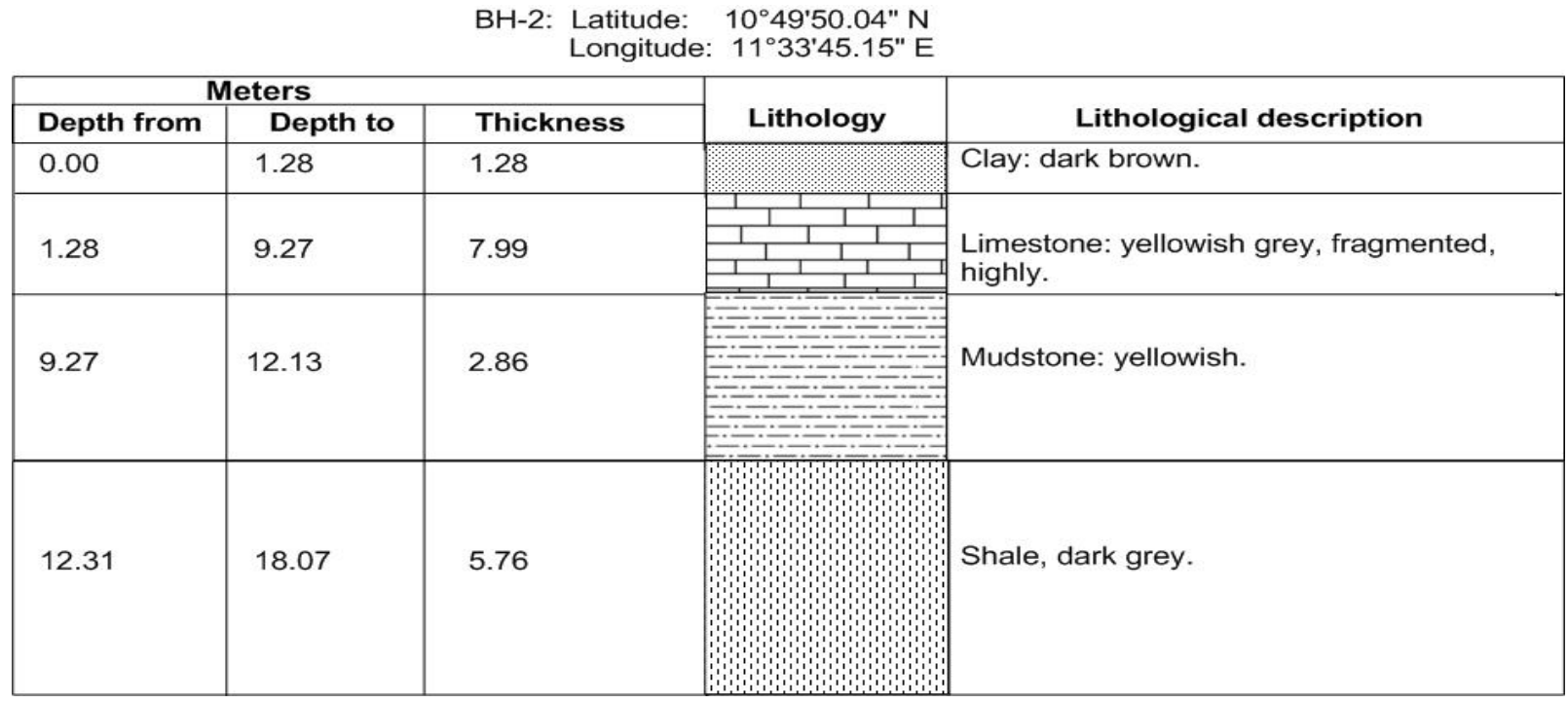

Figure 6: Lithological description of Borehole 2 at Kushimaga area, North-eastern Nigeria 


\subsubsection{Borehole No - 2 (Figure 6)}

The coordinates of the borehole are latitude $10^{0} 49^{1}$ $50.04^{11} \mathrm{~N}$ and longitude $11^{0} 33^{1} 45.15^{11} \mathrm{E}$. Shale which is dark grey in color was identified at the bottom of this borehole, followed by Mudstone bed with yellowish grey-reddish in places and weathered in places. This mudstone bed is overlain by limestone bed which is yellowish gray in color and is highly fragmented. Dark brown clay bed was identified on the top of limestone bed.

\subsubsection{Borehole No - 3 (Figure 7)}

This borehole is situated at latitude $10^{0} 48^{1} 44.94^{11} \mathrm{~N}$ and longitude $11^{0} 33^{1} 45.32^{11} \mathrm{E}$. From the bottom of the bed a shale bed was identified with grading from grey to black shale. The top is weathered while the base is fresh. The limestone bed which follows upwards has yellowish grey color it is weathered and fragmented on top and compacted at base. This is overlain by Shale bed is weathered and highly ferrogenized with yellowish grey color. This bed is followed upwards by yellowish grey color limestone concentrations. The top at this borehole comprises of dark brown soil.

\subsubsection{Borehole No - 4 (Figure 8)}

The borehole is located at latitude $10^{0} 48^{1} 44.85^{11} \mathrm{~N}$ and longitude $11^{0} 35^{1} 56.70^{11} \mathrm{E}$. A black shale bed was encountered at the bottom and this is followed by a grey hard limestone (marl) bed. On the top of the marl, a limestone bed was identified which is highly cavernous at base. It is yellowish grey and soft in places and this is overlain by yellowish grey shale bed. This bed is followed upward by a limestone bed again consisting of concretions. The bed is yellowish grey in colour, fossilized and fragmented. Then a bed of yellowish to yellowish grey shale followed which is overlain by dark brown topsoil, clay and sandy finedgrained materials.

\begin{tabular}{|c|c|c|c|c|}
\hline \multicolumn{3}{|c|}{ Meters } & \multirow[b]{2}{*}{ Lithology } & \multirow[b]{2}{*}{ Lithological description } \\
\hline Depth from & Depth to & Thickness & & \\
\hline 0.00 & 2.64 & 2.64 & & Top soil: Clay, dark brown and weathered. \\
\hline 2.64 & 3.34 & 0.70 & 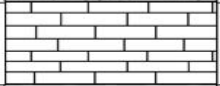 & $\begin{array}{l}\text { Limestone concretion, yellowish grey, } \\
\text { intercalated with shale fragmented, on } \\
\text { top and compacted. }\end{array}$ \\
\hline 3.34 & 6.70 & 3.36 & Ez= & $\begin{array}{l}\text { Shale:Yellowish grey, ferrogenized and } \\
\text { weathered. }\end{array}$ \\
\hline 6.70 & 11.89 & 5.19 & \begin{tabular}{|l|l|l|l|} 
& 1 \\
\end{tabular} & $\begin{array}{l}\text { Limestone: Yellowish grey, weathered and } \\
\text { fragemented on top and compated at base. }\end{array}$ \\
\hline 11.89 & 25.0 & 13.61 & 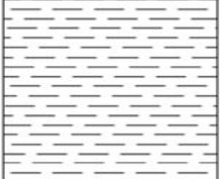 & $\begin{array}{l}\text { Shale: grading from grey to black shale, } \\
\text { weathered on top and fresh at base. }\end{array}$ \\
\hline
\end{tabular}

Figure 7: Lithological description of Borehole 3 at Kushimaga area, North-eastern Nigeria

\begin{tabular}{|c|c|c|c|c|}
\hline \multicolumn{2}{|c|}{ Meters } & & & \\
\hline Depth from & Depth to & Thickness & Lithology & Lithological description \\
\hline 0.00 & 1.08 & 1.08 & $\therefore \because \div$ & $\begin{array}{l}\text { Top soil: Clay, dark brown, sandy fined } \\
\text { grained. }\end{array}$ \\
\hline 1.08 & 9.37 & 8.29 & & $\begin{array}{l}\text { Shale, yellowish to yellowish grey, } \\
\text { gypsyferous. }\end{array}$ \\
\hline 9.37 & 10.27 & 0.90 & 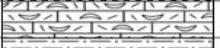 & $\begin{array}{l}\text { Limestone, concretion, yellowish grey, } \\
\text { fossilied and gragmented. }\end{array}$ \\
\hline 10.27 & 14.80 & 4.53 & $\begin{array}{r}\square \\
\square \\
\square\end{array}$ & Shale, yellowish grey. \\
\hline 14.80 & 18.37 & 3.57 & 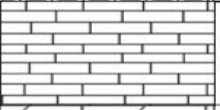 & $\begin{array}{l}\text { Limestone: yellowish grey soft in places, } \\
\text { higly carveneous at base gradation. }\end{array}$ \\
\hline 18.37 & 22.80 & 4.43 & 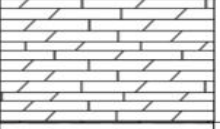 & Grey, hard, limestone (marl) \\
\hline 22.8 & 25.01 & 2.21 & $=1$ & Black shale. \\
\hline
\end{tabular}

Figure 8: Lithological description of Borehole 4 at Kushimaga area, North-eastern Nigeria. 


\subsection{Petrography of Kushimaga limestones.}

The limestone is grey to brownish, homogenous, composition dominated by calcite with crystal size of 0.0 to $0.05 \mathrm{~mm}$. The limestone samples (Figure 9) are composed (visual estimate) of over $95 \%$ calcite, trace amounts of colourless already recrystallized fossil of planktonic forams and mollusc, weakly compacted greenish grains of glauconite about 0.2 to $0.3 \mathrm{~mm}$ in grain size, traces of opaque, isotropic, high relief with 0.03 to $0.5 \mathrm{~mm}$ grains sizes iron oxide minerals are present disseminated mainly in the form of limonite. Traces of quartz and feldspar grains of silt size class were also noted in thin section. With less than $10 \%$ grains the samples are classified as mudstone using Dunham classification scheme. The presence of glauconitic grains suggests a shallow marine environment of deposition. The relatively high amount of silica shown by the chemical analysis is not reflected in the petrographic observation. However, such grains may be disseminated fine grain within the micritic matrix.

\subsection{Geochemistry of Kushimaga Limestone.}

Results of the geochemical analysis of major elements of the Kushimaga limestones are presented in Table 1.

The result of the Silica $\left(\mathrm{SiO}_{2}\right)$ content carried out on limestone samples shows a range between $10.05 \mathrm{wt} \%$ to $32.00 \mathrm{wt} \%$ with an average value of $17.66 \mathrm{wt} \%$. This average value is much higher than $5.58 \mathrm{wt} \%$ as reported by [5], for the Bularafa limestone located $50 \mathrm{~km}$ South-east of Kushimaga.

The lime ( $\mathrm{CaO})$ in the limestone samples range $21.00 \mathrm{wt} \%$ to $53.99 \mathrm{wt} \%$ with an average value of $40.05 \mathrm{wt} \%$. This average value is lower than $48.22 \mathrm{wt} \%$ as studied by [5] for the Bularafa limestone deposit.

The magnesia (MgO) content in the limestone samples indicates a range between $0.35 \mathrm{wt} \%$ to $1.00 \mathrm{wt} \%$ with an average value of $0.63 \mathrm{wt} \%$. The average value $(1.87 \mathrm{wt} \%)$ of Bularafa limestone deposit located $50 \mathrm{~km}$ South-eastern Kushimaga is slightly higher than that of Kushimaga limestone deposit.

Alumina $\left(\mathrm{Al}_{2} \mathrm{O}_{3}\right)$ in the Kushimaga limestone samples range from $2.15 \mathrm{wt} \%$ to $12.69 \mathrm{wt} \%$ with an average value of $5.61 \mathrm{wt} \%$. This average value is greater than $2.97 \mathrm{wt} \%$ as published by [5] for the same Bularafa limestone.

Iron $\left(\mathrm{Fe}_{2} \mathrm{O}_{3}\right)$ content vary from $1.28 \mathrm{wt} \%$ to $4.90 \mathrm{wt} \%$ in the limestone samples with an average value of $2.07 \mathrm{wt} \%$ which is also higher compared to $1.47 \mathrm{wt} \%$ for Bularafa as reported by [5].

The Potassium $\left(\mathrm{K}_{2} \mathrm{O}\right)$ of limestone range between $0.9 \mathrm{wt} \%$ to $1.96 \mathrm{wt} \%$ with an average value of $0.87 \mathrm{wt} \%$. However, the Bularafa's limestone average value of $0.36 \mathrm{wt} \%$ is less than compared to Kushimaga limestone.
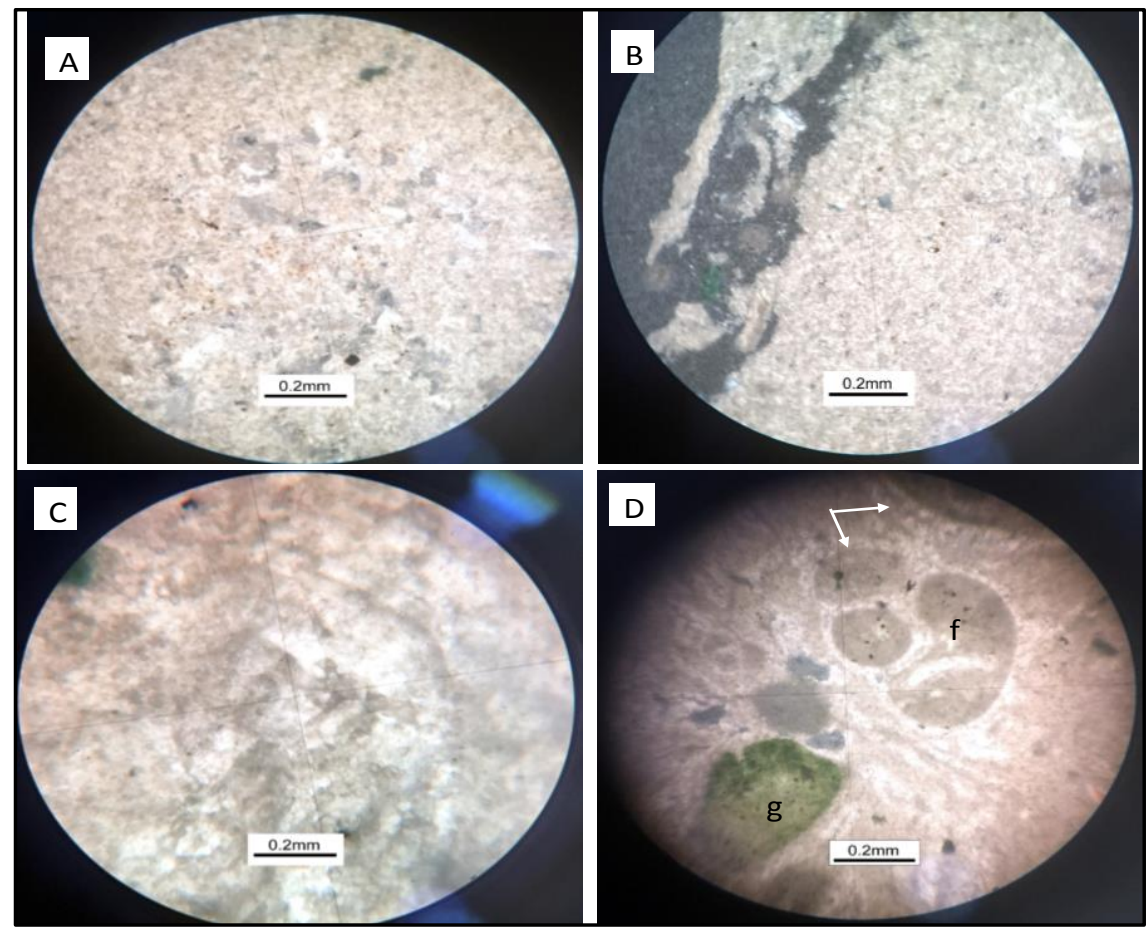

Figure 9: Thin section photomicrograph of grey to brown micritic limestone showing $(A)$ mudstone texture with silt size quartz crystals BH-1 (B and $C$ ) argillaceous texture $B H-2$ and $B H-3$, and (D) micrite with glauconitic grain $(g)$ and recrystallized bioclastic materials ( $f$ ) and white arrows $B H-4$. 
Table 1: Major oxides composition (wt\%) in Kushimaga limestones.

\begin{tabular}{cccccccccccc}
\hline Sample & $\mathrm{BH} 1-1$ & $\mathrm{BH} 1-2$ & $\mathrm{BH} 2-1$ & $\mathrm{BH} 2-2$ & $\mathrm{BH} 2-3$ & $\mathrm{BH}-1$ & $\mathrm{BH}-2$ & $\mathrm{BH}-3$ & $\mathrm{BH} 4-1$ & $\mathrm{BH} 4-2$ & $\mathrm{BH} 4-3$ \\
\hline $\mathrm{S}_{\mathrm{i}} \mathrm{O}_{2}$ & 15.69 & 10.05 & 14.21 & 24.99 & 25.99 & 10.75 & 10.72 & 15.50 & 32.00 & 17.55 & 16.80 \\
$\mathrm{AlO}_{2}$ & 6.45 & 2.15 & 4.05 & 6.88 & 5.98 & 4.10 & 3.40 & 3.60 & 12.69 & 6.50 & 5.90 \\
$\mathrm{Fe}_{2} \mathrm{O}_{3}$ & 2.05 & 1.28 & 1.78 & 1.58 & 1.63 & 2.05 & 1.69 & 1.35 & 4.90 & 2.25 & 2.23 \\
$\mathrm{CaO}$ & 39.15 & 45.97 & 42.90 & 32.99 & 33.72 & 43.99 & 53.99 & 41.93 & 21.00 & 47.50 & 37.40 \\
$\mathrm{MgO}$ & 0.55 & 1.00 & 0.40 & 0.61 & 0.40 & 0.35 & 0.60 & 0.50 & 0.90 & 0.80 & 0.80 \\
$\mathrm{SO}_{3}$ & 0.10 & 0.18 & 0.05 & 0.09 & 0.03 & 0.09 & 0.30 & 0.19 & 1.70 & 1.18 & 0.90 \\
$\mathrm{Na}_{2} \mathrm{O}$ & 0.01 & 0.09 & 0.002 & 0.02 & 0.11 & 0.01 & 0.03 & 0.00 & 0.18 & 0.00 & 0.02 \\
$\mathrm{~K}_{2} \mathrm{O}$ & 0.37 & 0.57 & 0.47 & 1.67 & 1.96 & 0.29 & 0.55 & 1.17 & 0.90 & 0.69 & 0.88 \\
$\mathrm{TiO}_{2}$ & 0.29 & 0.25 & 0.39 & 0.40 & 0.40 & 0.31 & 0.21 & 0.23 & 1.00 & 0.41 & 0.33 \\
$\mathrm{P}_{2} \mathrm{O}_{5}$ & 0.50 & 0.20 & 0.69 & 0.30 & 0.22 & 0.18 & 0.31 & 0.17 & 0.45 & 0.19 & 0.30 \\
$\mathrm{Mn}_{2} \mathrm{O}_{3}$ & 0.38 & 0.29 & 0.40 & 0.30 & 0.55 & 0.27 & 0.29 & 0.35 & 0.24 & 0.23 & 0.21 \\
$\mathrm{LOI}$ & 32.99 & 36.87 & 34.61 & 28.05 & 28.15 & 35.99 & 27.69 & 34.70 & 22.99 & 21.98 & 33.33 \\
$\mathrm{TOTAL}$ & 98.53 & 98.9 & 99.95 & 97.88 & 99.14 & 98.38 & 99.78 & 99.69 & 98.95 & 99.28 & 99.1 \\
\hline
\end{tabular}

Sodium $\left(\mathrm{Na}_{2} \mathrm{O}\right)$ in this research range from $0.002 \mathrm{wt} \%$ to $0.18 w t \%$ with an average value of $0.04 w t \%$. This result average value is much lower than $0.33 \mathrm{wt} \%$ as analyzed by [5] for the Bularafa limestone.

Other oxides, $\mathrm{Mn}_{2} \mathrm{O}_{3}, \mathrm{TiO}_{2}, \mathrm{SO}_{2}, \mathrm{P}_{2} \mathrm{O}_{5}$ and LOI are the other constituents present in the limestone samples. The percentages are show in Table 1.

\subsection{Bivariant Plots}

Magnesium oxide (MgO), $0.35 \mathrm{wt} \%$ to $1.00 \mathrm{wt} \%$ in Kushimaga limestone (Table 1).

Concentration of $\mathrm{MgO}$ plotted against $\mathrm{SiO}_{2} / \mathrm{Fe}_{2} \mathrm{O}_{3}$, Figures 10 and 11 shows positive correlation and with $\mathrm{CaO}$ (Figure 12) it shows negative correlation, which thus indicates that, the $\mathrm{MgO}$ and $\mathrm{Fe}_{2} \mathrm{O}_{3}$ percentage increases with leaching of $\mathrm{CaO}$ by solutions [11].

Silica oxide $\left(\mathrm{SiO}_{2}\right)$, content varies from $10.05 \mathrm{wt} \%$ to $32.00 \mathrm{wt} \%$ in Kushimaga limestone as presented in Table 1. Bivariant plots of $\mathrm{SiO}_{2}$ with $\mathrm{MgO}$ and $\mathrm{Fe}_{2} \mathrm{O}_{3}$ Figures 13 and 14 shows positive correlations, while that with $\mathrm{CaO}$ (Figure 15) show negative correlations which thus indicates that the $\mathrm{SiO}_{2}$ percentage decrease with increase in $\mathrm{CaO}$

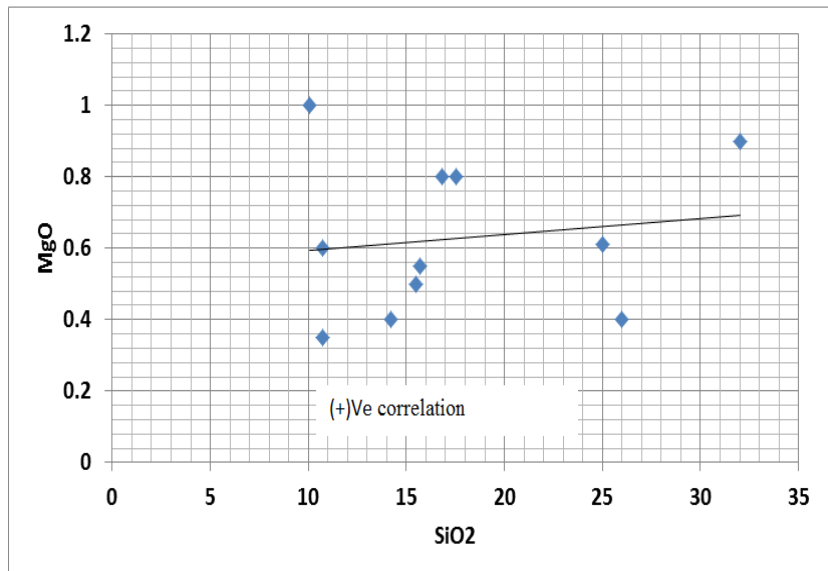

Figure 10: Plot of MgO/SiO2 of Kushimaga limestone.
Calcium oxide (CaO), $21.00 w t \%$ to $53.99 w t \%$ in Kushima limestone as recorded in Table 1. Concentration of $\mathrm{CaO}$ plotted against $\mathrm{SiO}_{2}, \mathrm{MgO}, \mathrm{Al}_{2} \mathrm{O}_{3}$ and $\mathrm{Fe}_{2} \mathrm{O}_{3}$ Figures 16, 17, 18 and 19 shows negative correlations. This thus indicates that $\mathrm{CaO}$ percentage decreases with increase of $\mathrm{SiO}_{2}, \mathrm{MgO}, \mathrm{Al}_{2} \mathrm{O}_{3}$ and $\mathrm{Fe}_{2} \mathrm{O}_{3}$. Aluminium oxide $\left(\mathrm{Al}_{2} \mathrm{O}_{3}\right)$ is found to be varying from $2.15 w t \%$ to $12.69 w t \%$ in Kushimaga limestone (Table 1). Aluminium oxide show negative correlation with Calcium oxide (Figure 20).

Iron oxide $\left(\mathrm{Fe}_{2} \mathrm{O}_{3}\right)$, the distribution of $\mathrm{Fe}_{2} \mathrm{O}_{3}$ is found to be varying from $1.28 w t \%$ to $4.90 w t \%$ in Kushimaga limestone as presented in Table 1. The bivariant plots of $\mathrm{Fe}_{2} \mathrm{O}_{3}$ against $\mathrm{SiO} 2$ and $\mathrm{MgO}(+)$ Vely correlated Figure 21 and 22 while (-)vely correlated $\mathrm{CaO}$ as presented as Figure 23. The fluctuation (increase or decrease) in Fe203 content may be related with terrigeneous influx associated with high Iron bearing solutions. The higher amount of $\mathrm{Fe}_{2} \mathrm{O}_{3}$ in carbonate rocks lowers the absorption capacity with lowers the rate of ignition of the samples.

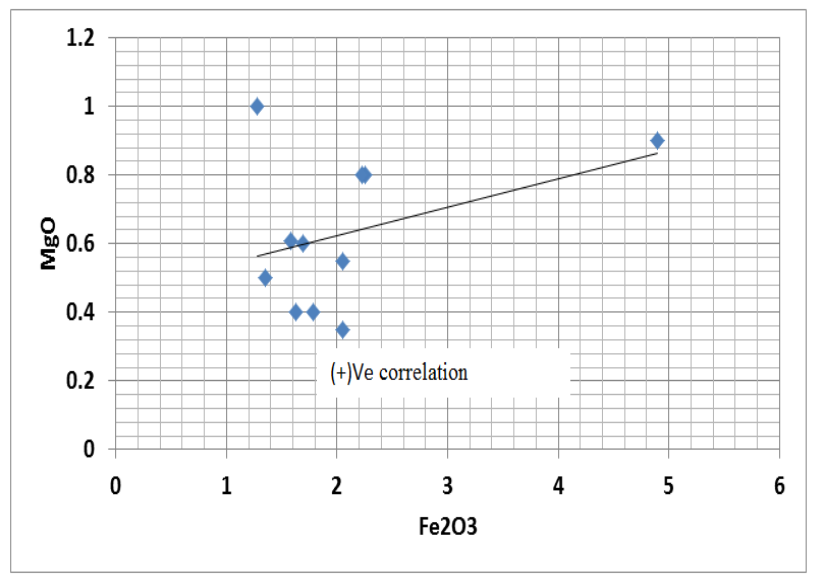

Figure 11: Plot of $\mathrm{MgO} / \mathrm{Fe}_{2} \mathrm{O}_{3}$ of Kushimaga limestone. 


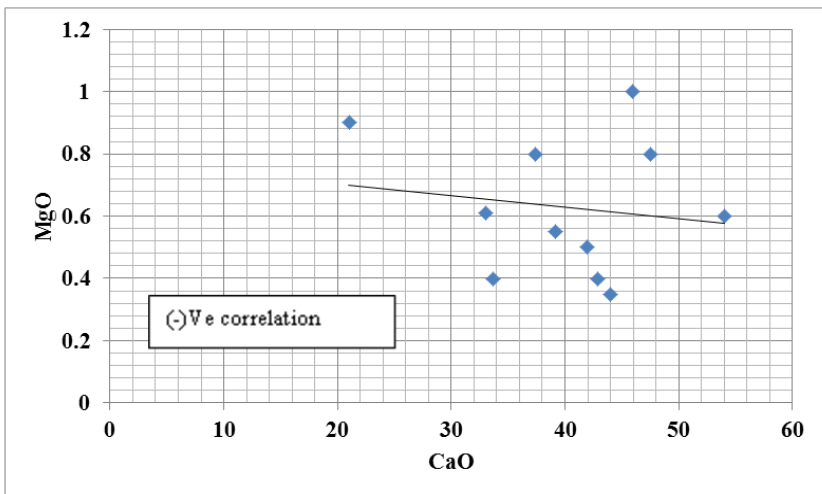

Figure 12: Plot of $\mathrm{MgO} / \mathrm{CaO}$ of Kushimaga limestone

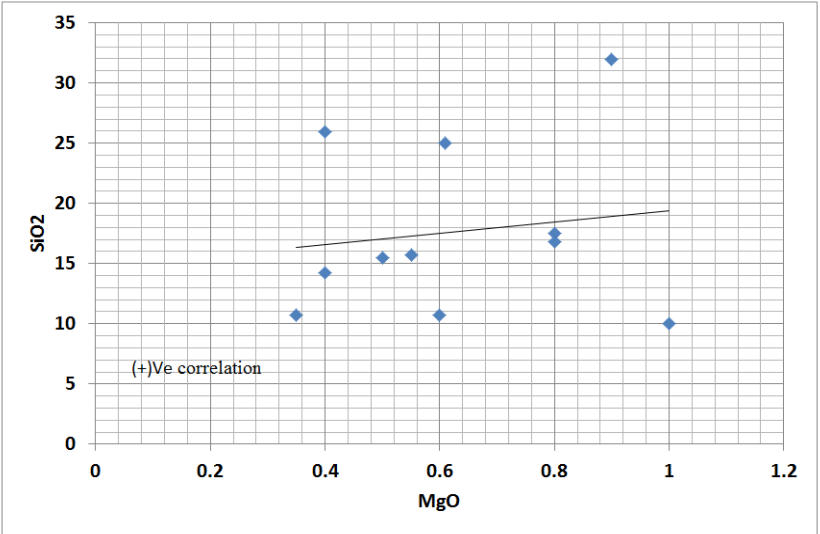

Figure 14: Plot of $\mathrm{SiO}_{2} / \mathrm{MgO}$ of Kushimaga limestone.

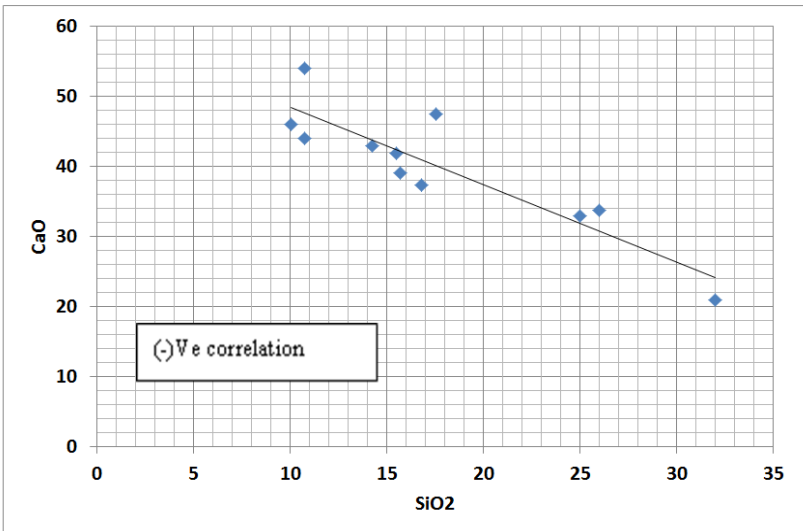

Figure 16: Plot of $\mathrm{CaO} / \mathrm{SiO}_{2}$ of Kushimaga limestone

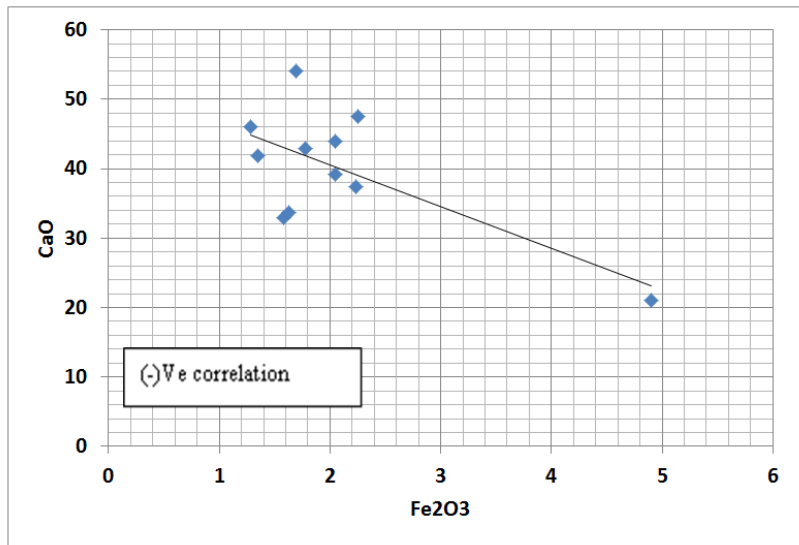

Figure 18: Plot of $\mathrm{CaO} / \mathrm{Fe}_{2} \mathrm{O}_{3}$ of Kushimaga limestone.

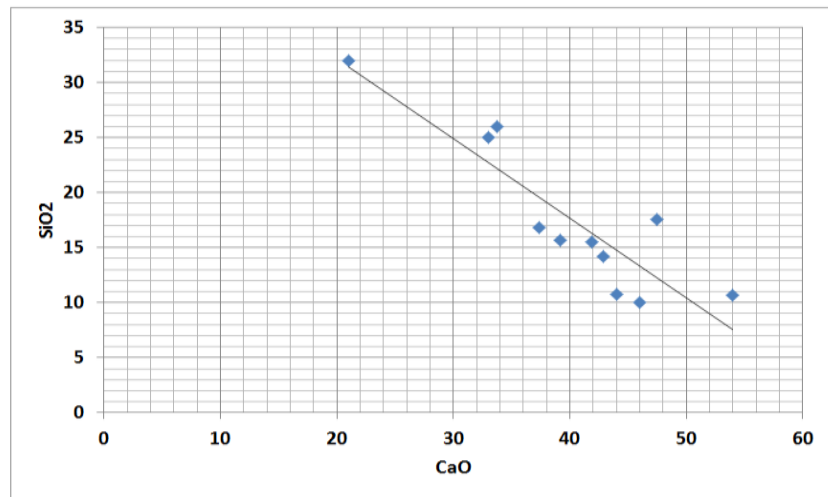

Figure 13: Plot of $\mathrm{SiO}_{2} / \mathrm{CaO}$ of Kushimaga limestone

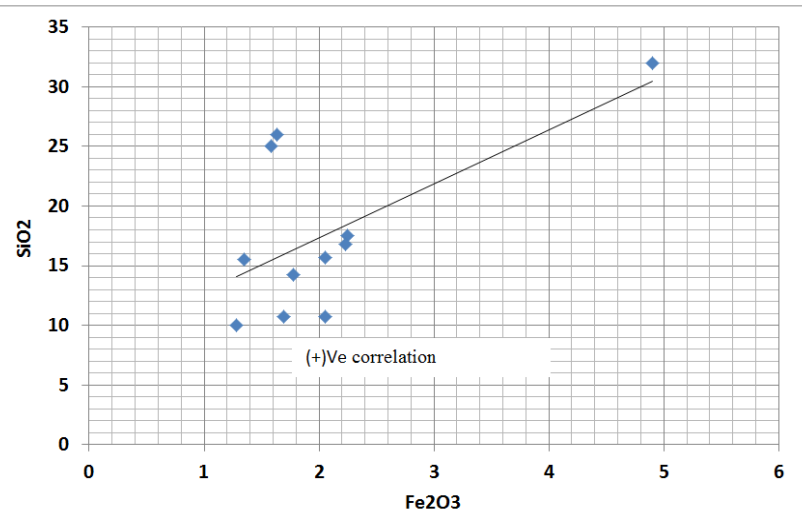

Figure 15: Plot of $\mathrm{SiO}_{2} / \mathrm{Fe}_{2} \mathrm{O}_{3}$ of Kushimaga limestone.

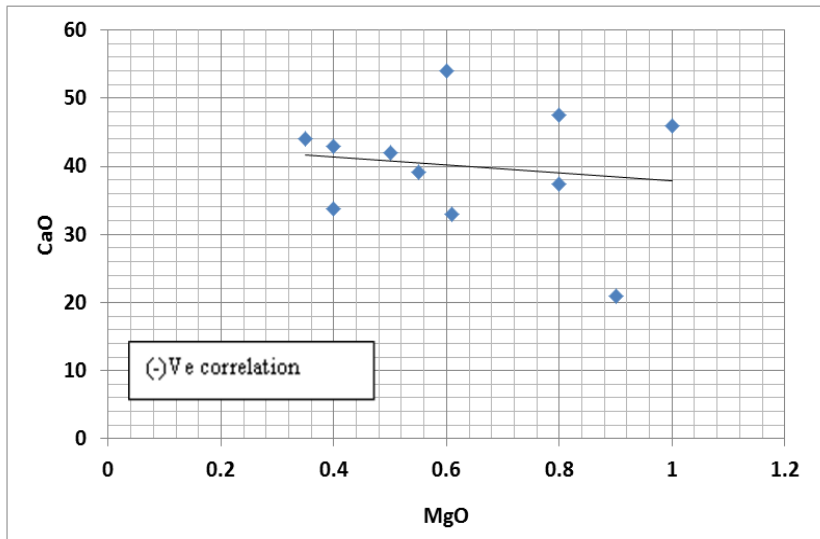

Figure 17: Plot of CaO/MgO of Kushimaga limestone

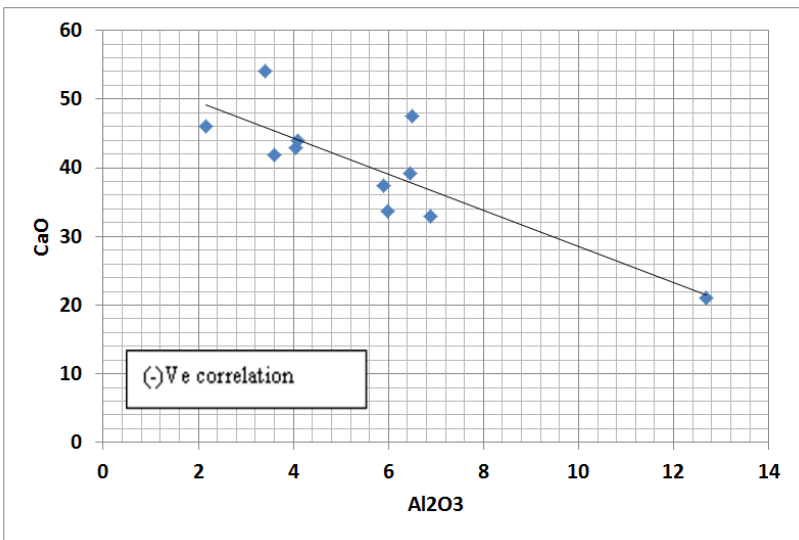

Figure 19: Plot of $\mathrm{CaO} / \mathrm{Al}_{2} \mathrm{O}_{3}$ of Kushimaga limestone 


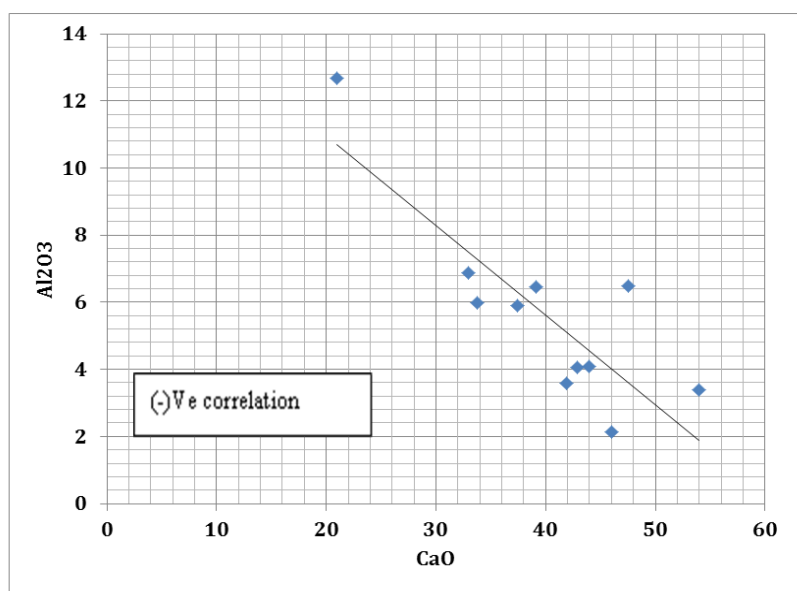

Figure 20: Plot of $\mathrm{AlO}_{2} / \mathrm{CaO}$ of Kushimaga limestone.

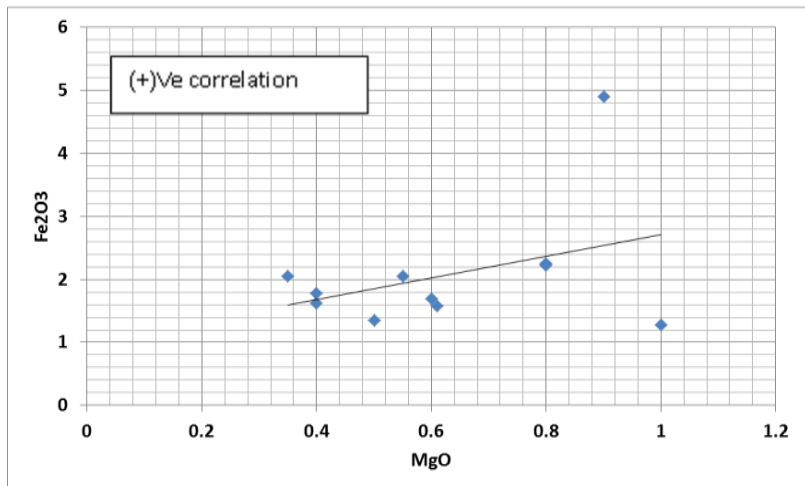

Figure 22: Plot of $\mathrm{Fe}_{2} \mathrm{O}_{3} / \mathrm{MgO}$ of Kushimaga limestone.

\subsection{Geochemical classification}

The distribution of $\mathrm{Ca} / \mathrm{Mg}$ ratio and it's reciprocal $\mathrm{Mg} / \mathrm{Ca}$ ratio are used as parameter for chemical classification of limestone according to [35]. The $\mathrm{Ca} / \mathrm{Mg}$ ratio of the Kushimaga limestone varies from $23.33 \mathrm{wt} \%$ to $125.68 \mathrm{wt} \%$ while the $\mathrm{Mg} / \mathrm{Ca}$ ratio vary from $0.00 w t \%$ to $0.04 w t \%$ (Table 2). Therefore, the $\mathrm{Ca} / \mathrm{Mg}$ ratios of the Kushimaga limestone are high.

[24] reported that $\mathrm{Ca} / \mathrm{Mg}$ ratio of carbonate rocks are proportionate to dolomite/calcite ratio and $\mathrm{Mg} / \mathrm{Ca}$ ratio of carbonate sediments which increases on going away from the shoreline which is related with the abundance of $\mathrm{Mg}$ rich coralline algae in near shore

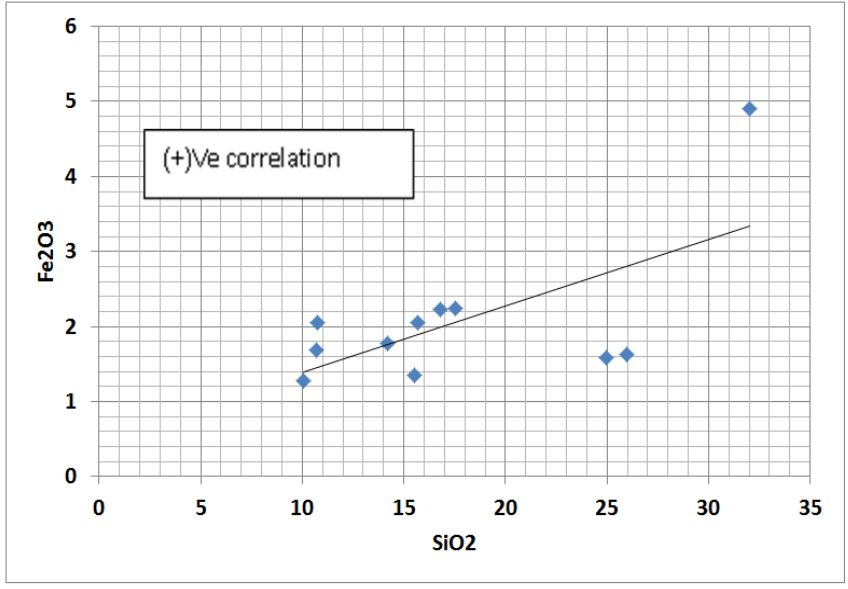

Figure 21: Plot of $\mathrm{Fe}_{2} \mathrm{O}_{3} / \mathrm{S}_{\mathrm{i}} \mathrm{O}_{2}$ of Kushimaga limestone.

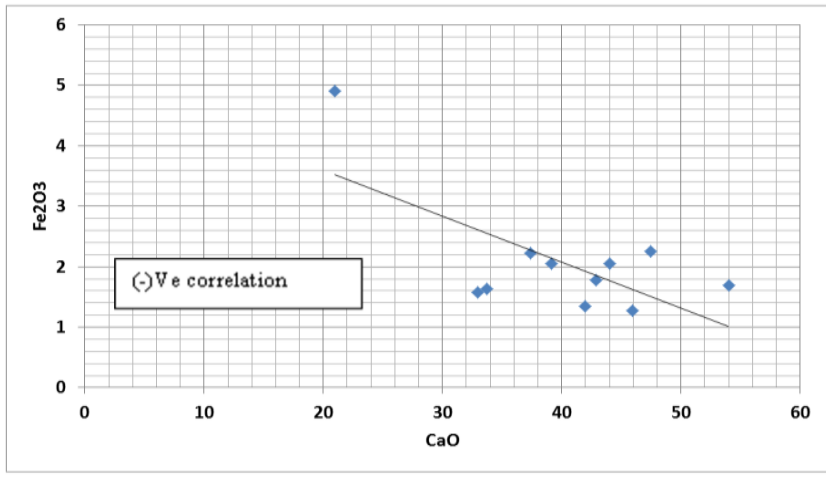

Figure 23: Plot of $\mathrm{Fe}_{2} \mathrm{O}_{3} / \mathrm{CaO}$ of Kushimaga limestone.

water. The results in this work indicates deposition of limestone in the proximity of a shoreline. The results also show that the Kanawa Member at Kushimaga is almost wholly formed by pure limestone.

The $\mathrm{Ca} / \mathrm{Mg}$ ratio also corresponds to stability condition during the formation of carbonate rock [24]. He explained out that the degree of salinity increases with decrease of $\mathrm{Ca} / \mathrm{Mg}$ ratio. Therefore, the higher values of $\mathrm{Ca} / \mathrm{Mg}$ ratio of this carbonate rocks in this work indicates comparatively less evaporation of sea water and low salinity that prevailed during the formation of the limestone in general.

Table 2: Chemical classification of Kushimaga carbonates

\begin{tabular}{|c|c|c|c|c|c|c|c|c|}
\hline $\mathrm{S} / \mathrm{N}$ & Sample No. & $\mathrm{CaO}$ & $\mathrm{MgO}$ & $\mathrm{Ca} / \mathrm{Mg}$ & $\mathrm{Mg} / \mathrm{Ca}$ & Name & Members & Types \\
\hline 1 & BH1-1 & 39.15 & 0.55 & 71.18 & 0.01 & Argillaceous Limestone & \multirow{11}{*}{ 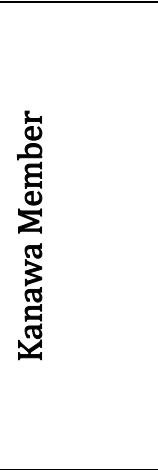 } & \multirow{11}{*}{ 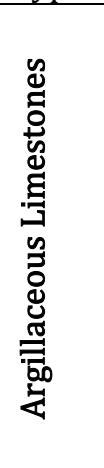 } \\
\hline 2 & BH1-2 & 45.97 & 1.00 & 45.97 & 0.02 & Argillaceous Limestone & & \\
\hline 3 & BH2-1 & 42.90 & 0.40 & 107.25 & 0.00 & Argillaceous Limestone & & \\
\hline 4 & BH2-2 & 32.99 & 0.61 & 54.08 & 0.01 & Argillaceous Limestone & & \\
\hline 5 & $\mathrm{BH} 2-3$ & 33.72 & 0.40 & 84.3 & 0.01 & Argillaceous Limestone & & \\
\hline 6 & BH3-1 & 43.99 & 0.35 & 125.68 & 0.00 & Argillaceous Limestone & & \\
\hline 7 & BH3-2 & 53.99 & 0.60 & 89.98 & 0.01 & Argillaceous Limestone & & \\
\hline 8 & BH3-3 & 41.93 & 0.50 & 83.86 & 0.01 & Argillaceous Limestone & & \\
\hline 9 & BH4-1 & 21.00 & 0.90 & 23.33 & 0.04 & Argillaceous Limestone & & \\
\hline 10 & BH4-2 & 47.50 & 0.80 & 59.37 & 0.01 & Argillaceous Limestone & & \\
\hline 11 & $\mathrm{BH} 4-3$ & 37.40 & 0.80 & 46.75 & 0.02 & Argillaceous Limestome & & \\
\hline
\end{tabular}




\subsection{Application}

This paper describes some industrial uses of limestone and gives chemical specifications for each use, where known.

Portland Cement: Limestone is the primary raw material used for making Portland cement, [20]. The chemical specifications, limestone used for cement making should commonly contain more than 75 percent calcium carbonate and less than 3 percent magnesia. Some specifications require less than 5 percent magnesium carbonate. Phosphorous pentoxide $\left(\mathrm{P}_{2} \mathrm{O}_{5}\right)$ should be less than 0.5 percent and sulfur should be low.

Paint pigments and filler: Whiting is used as pigment and/or filler in paints. The whiting may be made from either limestone, dolomite or magnesian limestone. The limestone should contain not less than 98 percent calcium carbonate (dry basis); dolomite or magnesian limestone should contain not less than 95 percent calcium carbonate and magnesian carbonate (dry basis) $[17 ; 23]$. Other specifications [10] state that "in general calcium carbonate content should exceed 96\% but magnesian limestones containing as much as $8 \%$ magnesium oxide are (rarely) tolerated - the $\mathrm{MgCO}_{3}$ content is generally $1 \%$. Other maxima are: $\mathrm{Fe}_{2} \mathrm{O}_{3}$ $0.25 \%, \mathrm{SiO}_{2}-2.0 \%$ and $\mathrm{SO}_{3}-0.1 \%$.

Sugar: Raw juice from sugar beets is agitated with milk of lime, and carbon dioxide is then passed through the juice. Impurities present are carried down by the precipitated calcium carbonate that forms which is then removed by thickening and filtration. The lime and carbon dioxide are made by burning limestone at the sugar factory. The chemical specification, a limestone of high purity is desired. Minimum calcium carbonate should be 96 percent [18] or 97 percent [36]. Silica should not exceed 1 percent and magnesia not more than 1 to 4 percent [17]. Another specification for silica sets a maximum of 4 percent [18]. Iron oxide is undesirable [17] and at some plants must not exceed 0.5 percent (California Division of Mines, 1959).

Glass: Limestone or dolomite in the raw state, or burned to lime, is an important constituent of the "batch" from which glass is made. Some glass batches contain 20 to 30 percent of limestone or dolomite. Limestone or dolomite should have uniform composition and high purity. The calcium carbonate content of the limestone probably should exceed 98 percent and calcium magnesium carbonate of dolomite 98 percent. Iron oxide should not be more than 0.05 percent and preferably less than 0.02 percent [10].

Asphalt filler: Limestone dust is used as filler for asphalt. No chemical specifications were noted; presumably the term limestone in specifications includes both the calcite and dolomitic types.

Paper: In the manufacture of chemical wood pulp for making paper in the tower system of the sulfite process, limestone in concrete towers is reacted with sulfur dioxide gas in the presence of water to form calcium bisulfite, $\mathrm{Ca}\left(\mathrm{HSO}_{3}\right)_{2}$. This compound, together with sulfurous acid also formed in the tower, is called "sulfite acid" and is used to digest wood chips so that a separation can be made of the cellulose in the wood from other unwanted constituents. The chemical specifications; the limestone should be high-calcium limestone low in magnesium, although a stone containing not more than 8 to 10 percent magnesium carbonate can be used [9].

Agricultural Limestone: Limestone and dolomite are applied to soil to correct soil acidity, add calcium and magnesium, improve soil structure, and maintain or promote conditions favorable for the utilization of soil nutrients by plants and for the growth of desirable soil organisms. Limestone and dolomite so used are variously referred to as agricultural limestone to the soil is called liming. The acid neutralizing value of agricultural limestone is for major significance and is measured in terms of the stone's calcium carbonate equivalent as chemical specification.

Therefore, Kushimaga limestone is more suitable in Portland cement manufacturing and is applicable in making asphalt filler, paper and in agricultural limestone etc. base on their chemical specifications.

\subsection{Geochemical Interpretation}

The distribution of $\mathrm{Ca} / \mathrm{Mg}$ ratio in the limestone samples suggests that the limestone samples of Kanawa Member are mainly pure limestones. In the current study, the high concentration of $\mathrm{Ca} / \mathrm{Mg}$ ratio beginning from 23.33 to 125.68 shows comparatively less evaporation of seawater during the time of limestone deposition [24]. The data in this work shows that the Kushimaga limestone is pure limestone and the deposition took place in the proximity of the shoreline [24].

The $\mathrm{CaO}$ percentage increases with decrease of other oxides present in the limestone. The calcium carbonate may be due to leaching of calcium by solution in the environment of deposition and subsequent precipitation. Change of environment is indicates by the increase of $\mathrm{SiO}_{2}$ content with the influx of terrigenous materials [7]. The presence of $\mathrm{Fe}_{2} \mathrm{O}_{3}$ and high $\mathrm{Ca}$ indicates reducing environment and deposition in closed basin [39]. Presence of few amounts of Phosphate and Manganese in the limestone shows a 
warm and humid climate during the deposition of carbonate sediments [21].

\section{SUMARRY AND CONCLUSIONS}

The study area is located within the eastern part of the Cretaceous Gomgola basin. The Pindiga Group in the study area comprises the Kanawa Member and the Gulani Member. Stratigraphy analysis suggest the Kushimaga limestone deposits, is of Kanawa Members. The argillaceous limestones are grey to brownish, homogenous, composition dominated by calcite minerals with crystal size of 0.00 to $0.05 \mathrm{~mm}$ and are massive in textures.

Petrography analyses revealed the presence of glauconitic grains suggest a shallow marine environment of deposition. The relatively high amount of silica shown by the chemical analysis is not reflected by significant siliceous grains in the petrographic observation. However, such grains may be disseminated fine grain within the micritic matrix. The results of geochemical analyses in the present study shows that the Kushimaga falls limestone under argillaceous limestone base on Todd's 1996 classification and that the deposition takes place in the proximity of the shoreline. Such environment was also suitable for receiving some terrigenous materials.

High values of $\mathrm{Ca} / \mathrm{Mg}$ ratio of the Kushimaga limestone indicates comparatively less evaporation of seawater and low salinity that prevailed during the formation of limestone.

Concentration of $\mathrm{MgO}$ in these limestones possibly results due to enriching of $\mathrm{MgO}$ by gradual removal of $\mathrm{CaO}$ during the diagenesis.

The chemical composition of the limestone of the study area are also satisfy the chemical requirements for Portland cement production but falls below standard of the specification for Paint pigments and filler, sugar and glass as a result of its higher Silica $\left(\mathrm{SiO}_{2}\right)$, Iron $\left(\mathrm{Fe}_{2} \mathrm{O}_{3}\right)$ composition.

\section{REFERENCES}

[1] Adegoke, A. K. "Biostratigraphy and depositional environment of the sediments in Borno Basin, North Eastern Nigeria" Indian Journal of Science and Technology, 5(6), pp 2800-2809, 2012.

[2] Akpan, I., Amodu, A., \& Akpan, "A. An assessment of the major elemental composition and concentration in limestones samples from Yandev and Odukpani areas of Nigeria using nuclear techniques", Journal of Environmental Science and technology, 4(3), pp 332-339, 2011a.

[3] Akpan, I., Amodu, A., \& Akpan, A. "Elemental analysis of limestone samples from Obajana and Mfamosing limestone deposits, Nigeria, using nuclear techniques", Applied Radiation and Isotopes, 69(10), pp 1355-1358, 2011b.

[4] Aliyu, A.H., Mamman, Y., Abubakar, M., Yandoka, B.M.S., Jitong, J.S., \& Shettima, B. "Paleodepositional environment and age of Kanawa Member of Pindiga Formation, Gongola Sub-basin, Northern Benue Trough, NE Nigeria: Sedimentological and palynological approach", Journal of African Earth Sciences, 134, pp 345-351, 2017.

[5] Baba S, El-Nafaty JM, Nkereuwem OT. "The occurrence of industrial mineral deposits in Yobe state, Nigeria", Research Journal of Science. (1)1, pp 34-45, 1995.

[6] Badmus, B., \& Olatinsu, O. "Geoelectric mapping and characterization of limestone deposits of Ewekoro formation, southwestern Nigeria", Journal of Geology and Mining Research, 1(1), pp 008-018, 2009.

[7] Baishya, D. K., Mahanta S. K. "A Geochemical Study of Sylhet Limestone around Umrangchu Area, North Cachar Hills District", Assam. Bull. Indian Geological. Association Vol. 27 (1), pp 63-67, 1994.

[8] Brennan, M. L., King, E. M., Shaw, L. C., Walling, S. L., \& Valdez Jr, F. "Preliminary geochemical assessment of limestone resources and stone use at Maya sites in the Three Rivers Region, Belize", Journal of Archaeological Science, 40(8), pp 31783192, 2013.

[9] Cadigan A. M. "Limestone and lime in the chemical pulp industry" Pit and Quarry, v. 35, no. 5, 1942, pp 74-78.

[10] California Division of Mines. "Limestone, dolomite and lime products" California Division of Mines, Mineral Information Service v. 12, no. 2, 1959, pp 8.

[11] Chilinger, G. V. "Relationship between $\mathrm{Ca} / \mathrm{Mg}$ ratio and geological age", Bulletin of American Association of Petroleum Geology 40, pp 22252226, 1956

[12] Ekwueme B. N. "The occurrence chemical composition and industrial quality of carbonate rocks in the Abini-Agoi area, south-eastern Nigeria", Nigeria Journal of Mining and Geology., (23)1 \&2, pp 5-9, 1987.

[13] El-Nafaty J. M. "Geology and petrography of the rocks around Gulani Area, Northeastern Nigeria", Journal of Geology and Mining Research. (7)5, pp 41-57, 2015.

[14] Elmagd, K. A., Emam, A., Ali-Bik, M. W., \& Hazem, M. "Geochemical assessment of Paleocene limestones of Sinn El-Kaddab Plateau, South Western Desert of Egypt, for industrial uses", Arabian Journal of Geosciences, 11(13), pp 355, 2018.

[15] Fatoye, F. B., \& Gideon, Y. B. "Geology and occurrences of limestone and marble in Nigeria", Journal of Natural Sciences Research, 3(11), pp 60 65, 2013. 
[16] Garba, I. "Geochemical discrimination of newly discovered rare-metal bearing and barren pegmatites in the Pan-African $(600 \pm 150 \mathrm{Ma})$ basement of northern Nigeria", Applied Earth Science, 112(3), pp 287-292, 2003.

[17] Goudge M. F. "Limestone in industry: Reprint from the Canadian Mining and Metallurgy", Bulletin, from Canadian Institute of Mining, Metallurgy and Trans., pp $4,6,7,1930$

[18] Hartmann E. M. "Lime and carbon dioxide production, in Beet-sugar technology (R. A McGinnis, ed.)", Reinhold Publishing Corporation, New York, pp 427-428, 1951.

[19] Idris, Y., Funtua, I., \& Umar, I. "Rapid analysis with energy-dispersive X-ray fluorescence spectrometry for bauxite investigation on the Mambilla Plateau, North Eastern Nigeria", Chemie der ErdeGeochemistry, 64(4), 2004, pp 385-398.

[20] Kennedy D. O., Moore B.M. Cement in Minerals Yearbook, U. S. Bureau of mines minerals yearbook, pp 281, 287, 1958

[21] Kotoky P., Kakaty T." Geochemistry of Siju Limestone, West Garo Hills, Meghalaya", Indian Journal of Geochemistry. Vol. 8 (1 and 2), pp 25-36, 1993.

[22] Konecny, P., Hagi, A., Plevova, E., Vaculikova, L., \& Murzyn, T. "Characterization of Limestone from Cement Plant at Berbera (Republic of Somaliland)", Procedia Engineering, 191, pp 43-50, 2017.

[23] Linsley C. M. "Limestone, how to use it, when to use it, where to use it" University of Illinois, Agriculture Extension Circular, 721, 1954, pp 6.

[24] Marshner H. Ca/Mg Distribution in Carbonates from the Lower Keuper in NW Germany (Development in Carbonate Sedimentology in Central Europe), pp 127-135, 1968.

[25] Noiriel, C., Luquot, L., Madé, B., Raimbault, L., Gouze, P., \& Van Der Lee, J. "Changes in reactive surface area during limestone dissolution: An experimental and modelling study", Chemical Geology, 265(1-2), pp 160-170, 2009.

[26] Overare, B., Etobro, A., Osokpor, J., Avwenagha, E., \& Ogueh, E. "Textural and Compositional Studies of Sediments from Parts of the Albian Bima Sandstone, Upper Benue Trough, Nigeria", Journal of Geography and Geology, 7(1), pp 97, 2015.

[27] Pettijohn F. J. Sedimentary Rocks; (Third Ed), Harper and Row, Publisher; New York, Evanston, San Francisco, 1975, pp 564

[28] Raji, J. K., \& Adebowale, A. O. J. "Petroleum Source Rock Potential of the Upper Benue Trough, Nigeria:
Implications for Hydrocarbon Exploration", Paper presented at the SPE Nigeria Annual International Conference and Exhibition, pp 1 - 10, 2015.

[29] Rao, D., Vijayakumar, T., Prabhakar, S., \& Raju, G. B. Geochemical assessment of a siliceous limestone sample for cement making. Chinese Journal of Geochemistry, 30(1), pp 33-39, 2011.

[30] Salako, K. "Depth to basement determination using Source Parameter Imaging (SPI) of aeromagnetic data: An application to upper Benue Trough and Borno Basin, Northeast, Nigeria", Academic Research International, 5(3), pp 74, 2014.

[31] Shettima, B., Abubakar, M., Kuku, A., \& Haruna, A. "Facies analysis, depositional environments and paleoclimate of the Cretaceous Bima Formation in the Gongola Sub-Basin, Northern Benue Trough, NE Nigeria", Journal of African Earth Sciences, 137, pp 193-207, 2018.

[32] Shettima, B., Kyari, A. M., Aji, M. M., \& Adams, F. D. "Storm and Tide influenced Depositional Architecture of the Pliocene-Pleistocene Chad Formation, Chad Basin (Bornu Sub-basin) NE Nigeria: A Mixed Fluvial, Deltaic, Shoreface and Lacustrine Complex", Journal of African Earth Sciences, Vol. 143, pp 309 - 320, 2018.

[33] Shettima, B., Tanko, I., Kuku, A., \& Adams, F "Sedimentology and Paleoenvironment of Deposition of the Deba-Fulani Member of Pindiga Formation in the Gongola Arm of the Upper Benue Trough, Northeastern Nigeria", Arid Zone Journal of Engineering, Technology and Environment, 12, pp 17-30, 2016

[34] Taylor, P. D., \& Zaborski, P. M. "A Late Cenomanian brayzoan biotrome from north-eastern. Nigeria", Cretaceous Research, 23(2), pp 242 - 253, 2002.

[35] Todd, T. W. "Petrographic classification of carbonate rocks", Journal of Sedimentary Petrology 36(2), pp 317-340, 1966.

[36] Turner, A. M. Use of limestone in the beet sugar industry: Rock Products, v. 35, no. 19, pp 18, 1932.

[37] Usman, M., Mamman, Y., Abubakar, U., Sulaiman, A., \& Hamidu, H. "Depositional environment of the Gombe Formation in the Gongola sub-basin of the northern Benue trough: Using grain size parameters", Global Journal of Geological Sciences, 15(1), pp 25-39, 2017.

[38] Wolfe, J. A. What to look for in selecting cement raw materials: Rock Products, v. 58, no. 8, 1955, pp 180.

[39] Wolf, K. H., Easton A. J., Warne, S. Development in Sedimentology. Techniques of Examining and Analyzing Carbonate Skeletons Minerals in Rocks, pp. 253-341, 1967. 